\title{
Zastosowanie termografii w medycynie - przegląd literatury
}

\section{The application of thermography in medicine - literature review}

\author{
Anna Modrzejewska ${ }^{1 凶}$, Mirosław Parafiniuk $^{2}$ \\ 1 Pomorski Uniwersytet Medyczny w Szczecinie, I Katedra i Klinika Okulistyki, al. Powstańców Wlkp. 72, 70-111 Szczecin \\ Pomeranian Medical University in Szczecin, First Chair and Clinic of Ophthalmology \\ ${ }^{2}$ Pomorski Uniwersytet Medyczny w Szczecinie, Zakład Medycyny Sądowej, al. Powstańców Wlkp. 72, 70-111 Szczecin \\ Pomeranian Medical University in Szczecin, Department of Forensic Medicine \\ $\triangle$ ania_modrzej@o2.pl
}

\begin{abstract}
Introduction: The purpose of this report was to present the application of thermal imaging in various fields of medicine including ophthalmology.

The application of thermography: Data in the literature indicate that the detection of infrared radiation emitted by various objects, including human tissues, can be successfully used in medicine. It is most often used to estimate the extent and severity of inflammation in the tissue, based on the phenomenon of high thermoemission caused by a local increase in blood supply and tissue metabolism.

Thermography is used in the diagnosis of arthritis, skin and eye inflammation. An increase of the temperature is observed in
\end{abstract}

cancerous tumors such as melanoma and hemangioma. Reduced temperature as a result of blood circulation disorders is shown by dynamic thermography in the Raynaud syndrome, after a heart attack, after skin burns and retinal ischemia. The eyes of patients with the dry eye syndrome have a lower temperature than healthy subjects, which may result from the lower emission of infrared radiation by the disturbed tear film.

Conclusion: Thermography is a non-invasive, fast and objective method that can be used in many areas of medicine in the future, including ophthalmology.

Keywords: thermography; thermovision camera; medicine; ophthalmology; dry eye syndrome; uveal melanoma.

\begin{abstract}
ABSTRAKT
Wstęp: Celem doniesienia jest przedstawienie zastosowania zjawiska termoemisji w różnych dziedzinach medycyny z uwzględnieniem okulistyki.

Zastosowanie tomografii: Dane w piśmiennictwie wskazują, że detekcja promieniowania podczerwonego, która jest emitowana przez różne obiekty, w tym tkanki ludzkie, może być wykorzystywana w medycynie. Termografia w medycynie najczęściej służy do oceny rozległości i nasilenia stanu zapalnego w badanej tkance na postawie zjawiska wysokiej termoemisji, czyli lokalnego wzmożonego ukrwienia i metabolizmu tkankowego. Używana jest w diagnostyce zapalenia stawów, skóry czy gałki ocznej. Wzrost temperatury obserwuje się w guzach
\end{abstract}

nowotworowych takich jak czerniak oraz naczyniak. Obniżenie temperatury jako efekt zaburzeń ukrwienia stwierdza się w termografii dynamicznej w Zespole Raynauda, po zawale serca, po oparzeniach skóry oraz w niedokrwieniu siatkówki. Zaobserwowano, iż w zespole suchego oka oczy chore mają niższą temperaturę niż oczy zdrowe, co może wynikać z niższej emisji promieniowania podczerwonego przez zaburzony film łzowy. Wnioski: Termografia jest metodą nieinwazyjną, szybką oraz obiektywną, która może znaleźć w przyszłości zastosowanie $\mathrm{w}$ wielu dziedzinach medycyny, w tym w okulistyce.

Słowa kluczowe: termografia; kamera termowizyjna; medycyna; okulistyka; zespół suchego oka; czerniak błony naczyniowej.

\section{WSTĘP}

Termografia jest metodą obrazowania, która wykrywa promieniowanie w zakresie podczerwieni o długości fali 9-14 $\mu \mathrm{m}$ emitowane przez różne obiekty, w tym tkanki ludzkie. Emisja promieniowania następuje powyżej zera bezwzględnego, czyli powyżej temperatury $-273,15^{\circ} \mathrm{C}$ lub o K. Efektem tego zjawiska jest powstanie obrazu w postaci termogramu, który w rzeczywistości jest wizualnym wskaźnikiem ilości energii podczerwonej emitowanej lub odbijanej przez tkankę. Badana tkanka porównywana jest do tzw. ciała doskonale czarnego (współczynnik równy 1,0), które absorbuje 100\% padającego promieniowana, oraz do tzw. ciała doskonale białego, które nie emituje promieniowania, całkowicie je odbijając [1]. Kamera termowizyjna pokazuje dokładną wartość i rozkład temperatury na badanej powierzchni, która uzależniona jest od unaczynienia i metabolizmu danej tkanki. Dzięki ustaleniu standardów pomiarowych dla termografii, rozwojowi technologii komputerowych oraz konstrukcji czułych detektorów termowizja jako narzędzie diagnostyczne staje się coraz częstszym obiektem zainteresowania w różnych dziedzinach medycyny. 


\section{ZASTOSOWANIE TERMOGRAFII W MEDYCYNIE}

Kamera termowizyjna w medycynie najczęściej wykorzystywana jest do oceny rozległości i nasilenia stanu zapalnego w badanej tkance na podstawie zjawiska wysokiej termoemisji, czyli lokalnego wzmożonego ukrwienia i metabolizmu tkankowego [2]. Technika ta dotychczas stosowana była w reumatologii do oceny zmian zapalnych w stawach, w laryngologii w diagnostyce zapalenia zatok nosowych, w stomatologii do analizy zapalenia stawów skroniowo-żuchwowych [3], jak też w endokrynologii w diagnostyce schorzeń tarczycy [4]. Termografia dynamiczna określa zmianę temperatury na badanym obszarze w przedziale czasu po zadziałaniu zewnętrznego bodźca termicznego takiego jak zimno lub ciepło. Zjawisko to jest również wykorzystywane do wczesnego rozpoznania zespołu Raynauda czy zaburzeń krążenia w obrębie kończyn dolnych [5]. Jak dotąd wiele prób wykorzystania kamery termowizyjnej w medycynie dotyczyło diagnostyki raka piersi. W piśmiennictwie można znaleźć dane wskazujące, iż termografia może być pomocna do wyznaczenia granicy pomiędzy obszarem tkanki zdrowej a zajętym procesem nowotworowym $[6,7,8]$. We wszystkich przypadkach podkreślana jest jednak konieczność uzupełnienia diagnostyki i wykonania badań specjalistycznych, tj. ultrasonografii oraz badania histopatologicznego. Zmiany pourazowe, zwyrodnieniowe i zwłóknieniowe przedstawiane są jako bardziej zimne w termografii w porównaniu ze zdrowymi fragmentami ciała. W fizykoterapii metoda ta używana jest w ocenie skuteczności różnych zabiegów fizykoterapeutycznych [3, 9]. Santa Cruz i wsp. stwierdzili, iż czerniaki skóry charakteryzują się wyższą temperaturą o ok. 2-4 K od skóry zdrowej [10]. Zgodnie z piśmiennictwem termografia może być przydatna do rozróżniania zmian łagodnych od czerniaków w zmianach skórnych powyżej 15 mm [11]. Udokumentowano również, iż guzy naczyniowe skóry charakteryzują się większą perfuzją i metabolizmem niż skóra zdrowa, czego efektem jest wzrost termoemisji obserwowany w badaniu kamerą termowizyjną [12]. W literaturze można znaleźć interesujące doniesienia wskazujące, iż za pomocą termografii można monitorować i oceniać skuteczność leczenia beta-blokerami dziecięcych naczyniaków skórnych oraz prognozować ich wzrost [13]. W ostatnich latach wykonuje się również próby zastosowania termowizji w ocenie krążenia w trakcie operacji w krążeniu pozaustrojowym, w wybranych procedurach kardiochirurgicznych [14] oraz w diagnostyce kardiologicznej u pacjentów po zawale serca, obserwując obniżenie ciepłoty skóry klatki piersiowej [15]. W transplantologii opisywane jest zastosowanie badań termowizyjnych do oceny czasu tzw. zimnego niedokrwienia podczas operacji chirurgicznych przeszczepiania nerki [16], w chirurgii do oceny rozległości oparzeń [17] oraz konieczności wykonania przeszczepu skóry po oparzeniu termicznym [18]. Termowizja ma również zastosowanie w medycynie sądowej w celu określenia czasu zgonu, wykorzystując zjawisko pośmiertnego schładzania się zwłok [19]. Co więcej, metoda ta może być również pomocna w celach epidemiologicznych do pomiaru temperatury ciała w miejscach użyteczności publicznej we wczesnym etapie zakażenia chorobami wirusowymi podczas pandemii (np. świńskiej grypy) [9].

\section{ZASTOSOWANIE TERMOGRAFII W OKULISTYCE}

W bazie PubMed zawarte są nieliczne pozycje piśmiennictwa dotyczące możliwości zastosowania termowizji w diagnostyce schorzeń gałki ocznej i oczodołu. Badania z różnych ośrodków dotyczą obrazowania stanu fizjologicznego oka, jak i obrazów termograficznych w wybranych schorzeniach gałkowych.

W grupie osób zdrowych temperatura powierzchni gałki ocznej wynosi średnio $34,02^{\circ} \mathrm{C} \pm 0,22$, przy czym wyniki różnych autorów wskazują na brak istotnych statystycznie różnic pomiędzy prawym a lewym okiem oraz pomiędzy kobietami a mężczyznami [20] (ryc. 1). Nie wykazano również zależności pomiędzy grubością rogówki i głębokością przedniej komory oka a temperaturą powierzchni gałki ocznej [21]. Uważa się, że cechy fizyczne pacjentów (owłosienie, otyłość, zmiany dermatologiczne skóry) ze względu na badaną okolicę mają niewielki wpływ na wyniki otrzymanych termogramów [22]. Udokumentowano również związek między temperaturą środowiska zewnętrznego i ciała człowieka a temperaturą rogówki [23]. Warunki środowiskowe, takie jak temperatura, mogą mieć dodatnią korelację z temperaturą powierzchni gałki ocznej do $0,15-0,2^{\circ} \mathrm{C}$ na każdy wzrost stopnia Celsjusza. Zmiany w przepływie powietrza i wilgotności w pomieszczeniu mogą zaburzać lokalną wymianę ciepła, dlatego zaleca się okres adaptacji w pomieszczeniu przed pomiarem kamerą termograficzną [24].

Istnieją doniesienia o zastosowaniu kamery termowizyjnej do obrazowania zaburzeń ukrwienia siatkówki [25] (ryc. 2), w diagnostyce retinopatii cukrzycowej [26] oraz w zwyrodnieniu plamki związanym z wiekiem (age-related macular degeneration - AMD) [27] (ryc. 3). Wyniki uzyskanych badań wskazują że gałki oczne z tymi schorzeniami wykazują niższy wskaźnik termoemisji w porównaniu z okiem bez tych patologii. Klamann i wsp. oceniali wydolność pęcherzyka filtracyjnego po operacji jaskry. Zaobserwowano, że szybszy spadek temperatury w jego obszarze świadczy o drożności i spadku ciśnienia gałki ocznej [28]. Pojedyncze doniesienia przedstawiają również możliwość zastosowania diagnostycznego termowizji zarówno w zapaleniach spojówek, jak i w stanach zapalnych tylnego odcinka oka, co ma szczególnie istotne znaczenie przy utrudnionym wglądzie w dno oka przy zmętniałych strukturach anatomicznych przedniego odcinka gałki ocznej. Gałka objęta schorzeniem uwidacznia się w termografii jako powierzchnia gorąca [29, 30] (ryc. 4 i 5).

Już w 1971 r. Kruszewki zauważył, iż niektóre nowotwory, takie jak czerniak czy naczyniak błony naczyniowej, uwidaczniają się w termowizji jako tzw. guzy gorące [2] (ryc. 6 i 7). Obserwacja ta znajduje potwierdzenie u innych autorów, którzy zaobserwowali, że temperatura powierzchni gałki ocznej jest wyższa w czerniakach spojówki i naczyniówki w porównaniu z gałkami ocznymi bez tych patologii [31]. Podkreśla się, iż czerniaki są guzami o znacznej aktywności 


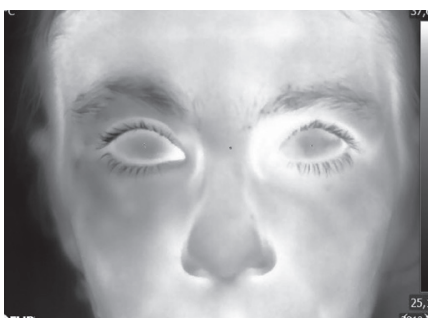

RYCINA 1. Zdjęcie termograficzne okolicy gałek ocznych kamerą FLIR T640 w odcieniach szarości. Stan fizjologiczny (materiał własny)

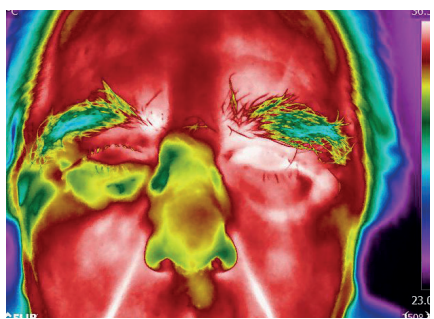

RYCINA 2. Zdjęcie termograficzne okolicy gałek ocznych kamerą FLIR T640. Zator tętnicy środkowej siatkówki oka prawego (materiał własny)

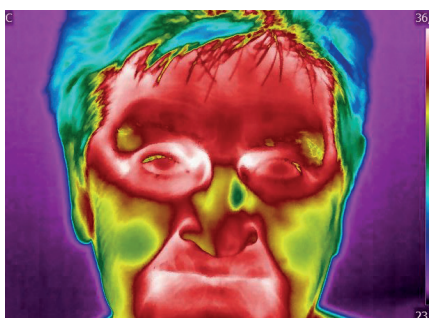

RYCINA 6. Zdjęcie termograficzne okolicy gałek ocznych kamerą FLIR T640. Czerniak naczyniówki oka prawego (materiał własny)

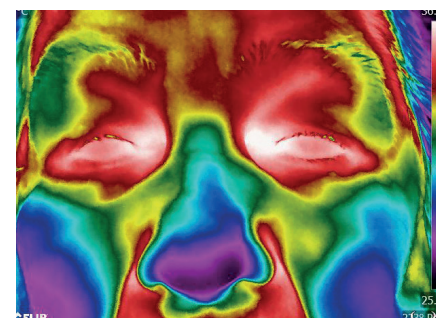

RYCINA 3. Zdjęcie termograficzne okolicy gałek ocznych kamerą FLIR T640. Zwyrodnienie plamki żółtej związanej z wiekiem (AMD) oka prawego (materiał własny)

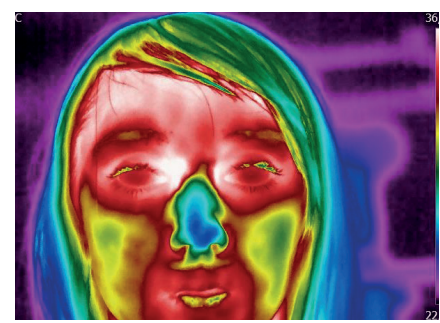

RYCINA 7. Zdjęcie termograficzne okolicy gałek ocznych kamerą FLIR T640. Naczyniak naczyniówki oka prawego (materiał własny)

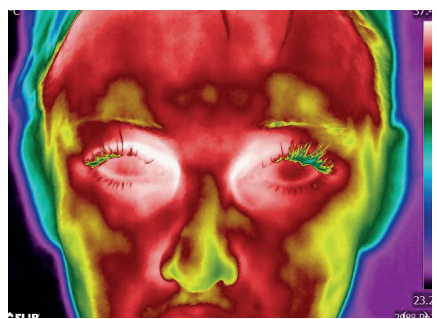

RYCINA 4. Zdjęcie termograficzne okolicy gałek ocznych kamera FLIR T640. Zapalenie bakteryjne spojówek oka prawego (materiał własny)
RYCINA 5. Zdjęcie termograficzn kolicy gałek ocznych kamerą wnętrza gatki ocznej prawej (materiat własny) termicznej, która wynika z obecności w masie guza nieprawidłowego unaczynienia i związanego z tym zjawiskiem zwiększenia metabolizmu tkankowego [32]. Najbardziej popularnym schorzeniem okulistycznym ocenianym za pomocą kamery termowizyjnej jest zespół suchego oka [33], w przypadku którego zaobserwowano, że oczy chore mają niższą temperaturę niż oczy zdrowe, co może wynikać z niższej emisji promieniowania podczerwonego gałki ocznej poprzez zaburzoną strukturę filmu łzowego [34, 35] (ryc. 8). Giannaccare i wsp. wykonali badania termograficzne oczu pacjentów w 7. i 28. dobie po operacji zaćmy, wykazując niższą temperaturę powierzchni oka w centralnej części rogówki i podwyższoną w jego skroniowej części w porównaniu ze stanem gałki ocznej przed operacją. Obserwowany spadek temperatury w obszarze centralnym części rogówki był najprawdopodobniej związany z zaburzeniem struktury filmu łzowego, a pomiar temperatury był odwrotnie skorelowany ze wskaźnikiem zaburzeń powierzchni oka (ocular surface disease index - OSDI) i z czasem przerwania filmu łzowego, tzw. TBUT (tear break-up time). Wzrost temperatury w części skroniowej rogówki przedstawiony został jako przejściowy stan zapalny gałki ocznej rozwijający się w odpowiedzi na zabieg operacyjny [36]. Obserwacje te zostały potwierdzone przez innych autorów, którzy wykazali związek pomiędzy obniżeniem temperatury powierzchni oka w trakcie $10 \mathrm{~s}$ po mrugnięciu a niestabilnością filmu łzowego mierzonego za pomocą TBUT i testu Schirmera [37, 38]. Morgan i wsp. stwierdzili ujemną korelację pomiędzy wiekiem pacjenta a temperaturą powierzchni oka, co może mieć związek $\mathrm{z}$ nasilającymi się z upływem lat objawami zespołu suchego oka [39]. Wyjaśnienia zjawiska ochładzania się powierzchni rogówki u osób starszych również upatruje się w zwiększeniu niestabilności i parowania filmu łzowego [40, 41, 42].

\section{WNIOSKI}

Przytoczone przykłady zastosowania kamery termowizyjnej w okulistyce świadczą o tym, że rola termowizji w szeregu schorzeniach gałki ocznej nie jest jak dotąd wyznaczona. Wyniki badań wskazują, że termografia może być metodą skriningową oraz pomocniczą w rozpoznawaniu zmian nowotworowych, zapalnych czy niedokrwiennych. Ponadto należy zaznaczyć, że współczesne kamery termowizyjne znacznie różnią się od urządzeń stosowanych w przeszłości. Obecnie oprócz wyznaczenia temperatury gałki ocznej możliwa jest analiza cyfrowa termogramów pozwalająca na zastosowanie rozległych analiz zmian ilościowych w obrazie. Wydaje się, iż termografia jako metoda bezkontaktowa, szybka, obiektywna oraz dająca wyniki w czasie rzeczywistym może znaleźć w przyszłości zastosowanie w wielu dziedzinach medycyny, w tym w okulistyce.

\section{PIŚMIENNICTWO}

1. Usamentiaga R, Venegas P, Guerediaga J, Vega L, Molleda J, Bulnes FG. Infrared thermography for temperature measurement and non-destructive testing. Sensors 2014;14(7):12305-48.

2. Kruszewski S. Zastosowanie termografii i termowizji w medycynie. Pol Przegl Radiol Med Nukl 1971;35(4):441-4. 
3. Cholewka A, Drzazga Z, Sieroń A, Stanek A. Thermovision diagnostics in chosen spine disease treated by whole body cryotheraphy. J Thermal Analysis Calorimetry 2010;102(1):113-9.

4. Helmy A, Holdmann M, Rizkalla M. Application of thermography for non-invasive diagnosis of thyroid gland disease. IEEE Trans Biomed Eng 2008;55(3):1168-75.

5. Ammer K. Diagnosis of Raynaud's phenomenon by thermography. Skin Res Technol 1996;2(4):182-5.

6. Zadeh HG, Haddadnia J, Ahmadinejad N, Baghdadi MR. Assessing the potential of thermal imaging in recognition of breast cancer. Breast Care 2015;16(18):8619-23.

7. Omranipour R, Kazemian A, Alipour S, Najafi M, Alidoosti M, Navid M, et al. Comparison of the accuracy of thermography and mammography in the detection of breast cancer. Breast Care 2016;11(4):260-4

8. Madhu H, Kakileti ST, Venkataramani K, Jabbireddy S. Extraction of medically interpretable features for classification of malignancy in breast thermography. Conf Proc IEEE Eng Med Biol Soc 2016;2016:1062-5.

9. Bauer J, Boerner E, Podbielska H. Termowizyjna ocena kolejności stosowania zabiegów fizykalnych. Biomedyczne zastosowania termowizji. Wrocław: Oficyna Wydawnicza Politechniki Wrocławskiej; 2014.

10. Santa Cruz GA, Bertotti J, Marin J, Gonzalez SJ, Gossio S, Alvarez D, et al. Dynamic infrared imaging of cutaneous melanoma and normal skin in patients treated with BNCT. Appl Radiat Isot 2009;67:S54-8.

11. Shada AL, Dengel LT, Petroni GR, Smolkin ME, Acton S, Slingluff CL Jr. Infrared thermography of cutaneous melanoma metastases. J Surg Res 2013;182(1):e9-14.

12. Burkes SA, Patel M, Adams DM, Hammill AM, Eaton KP, Randall Wickett R, et al. Infantile hemangioma status by dynamic infrared thermography: A preliminary study. Int J Dermatol 2016;55(10):e522-32.

13. Garcia-Romero MT, Chakkittakandiyil A, Pope E. The role of infrared thermography in evaluation of proliferative infantile hemangiomas. Results of a pilot study. Int J Dermatol 2014;53(3):e216-7.

14. Nowakowski A, Kaczmarek K, Rumiński J. The role of thermal monitoring in cardiosurgery interventions. In: Diakides M, Bronzino JD, Petereson DR, editors. Medical infrared imaging: principles and practices. Boca Raton: CRC Press, Taylor \& Francis Group; 2013. p. 17.1-17.24.

15. Prasał M, Sawicka KM, Wysokiński A. Termowizja jako metoda diagnostyczna stosowana w kardiologii. Kardiol Pol 2010;68(9):1052-6.

16. Pabisiak K, Romanowski M, Myslak M, Szydłowski L, Sieńko J, Domański L, et al. Variations in temperature of the donor kidney during cold ischemia time and subsequent assessment of reperfusion using the application of thermovision camera. Transplant Proc 2003;35(6):2157-9.

17. Xue EY, Chandler LK, Viviano SL, Keith JD. Use of FLIR ONE Smartphone thermography in burn wound assessment. Ann Plast Surg 2018;80(4):S236-8.

18. Simmons JD, Kahn SA, Vickers AL, Crockett ES, Whitehead JD, Krecker AK, et al. Early assessment of burn depth with far infrared time lapse thermography. J Am Coll Surg 2018;226(4):687-93.

19. Maksymowicz K, Dudek K, Bauer J, Jurek T, Drozd R. Ocena możliwości zastosowania techniki termowizyjnej w diagnostyce medyczno-sądowej. Podstawy teoretyczne. Ann Acad Med Stetin 2007;53(2):102-6.

20. Klamann MK, Maier AK, Gonnermann J, Klein JP, Pleyer U. Measurement of dynamic ocular surface temperature in healthy subjects using a new thermography device. Curr Eye Res 2012;37(8):678-83.

21. Pattmöller J, Wang J, Zemova E, Seitz B, Eppig T, Langenbucher A, et al. Correlation of corneal thickness, endothelial cell density and anterior chamber depth with ocular surface temperature in normal subjects. Z Med Phys 2015;25(3):243-50.
22. Bauer J, Dereń E. Standaryzacja badań termograficznych w medycynie i fizykoterapii. Inż Biomed 2014;20(1):11.

23. Kessel L, Johnson L, Arvidsson H, Larsen M. The relationship between body and ambient temperature and corneal temperature. Invest Ophthalmol Vis Sci 2010;51(12):6593-7.

24. Freeman RD, Fatt I. Environmental influences on ocular temperature. Invest Ophthalmol 1973;12(8):596-602.

25. Mapstone R. Ocular thermography. Br J Ophthalmol 1970;54:751-4.

26. Sodi A, Giambene B, Miranda P, Falaschi G, Corvi A, Menchini U. Ocular surface temperature in diabetic retinopathy: a pilot study by infrared thermography. Eur J Ophthalmol 2009;19(6):1004-8.

27. Sodi A, Matteoli S, Giacomelli G, Finocchio L, Corvi A, Menchini U. Ocular surface temperature in age-related macular degeneration. J Ophthalmol 2014:2014:281010.

28. Klamann MK, Maier AK, Gonnermann J, Klein JP, Ruokonen P, Pleyer U. Thermography: a new option to monitor filtering bleb function? J Glaucoma 2015;24(4):272-7.

29. Klamann MKJ, Maier AK, Gonnermann J, Klein JP, Bertelmann E, Pleyer U. Ocular surface temperature gradient is increased in eyes with bacterial corneal ulcers. Ophthalmic Res 2013;49:52-6.

30. Kawali AA. Thermography in ocular inflammation. Indian J Radiol Imaging 2013;23(3):281-3.

31. Wittig I, Kohlmann H, Lommatzsch PK, Krüger L, Herold H. Static and dynamic infrared thermometry and thermography in malignant melanoma of the uvea and conjunctiva. Klin Monatsbl Augenheilkd 1992;201(5):317-21.

32. Buzug TM, Schumann S, Pfaffmann L, Reinhold U, Ruhlmann J. Functional infrared imaging for skin-cancer screening. Conf Proc IEEE Eng Med Biol Soc 2006;1:2766-9.

33. Azharuddin M, Bera SK, Datta H, Dasgupta AK. Thermal fluctuation based study of aqueous deficient dry eyes by non-invasive thermal imaging. Exp Eye Res 2014;120:97-102.

34. Żelichowska B, Różycki R, Tłustochowicz M, Kujawa A, Kalicki B, Murawski P. Przydatność termografii w diagnostyce zespołu suchego oka. Klin Oczna 2005;107(7-9):483-7.

35. Azharuddin M, Bera SK, Datta H, Dasgupta AK. Thermal fluctuation based study of aqueous deficient dry eyes by non-invasive thermal imaging. Exp Eye Res 2014;120:97-102.

36. Giannaccare G, Fresina M, Agnifili L, Versura P. Ocular-surface temperature modification by cataract surgery. J Cataract Refract Surg 2016;42(7):983-9.

37. Shih SR, Li HY, Hsiao YL, Chang TC. The application of temperature measurement of the eyes by digital infrared thermal imaging as a prognostic factor of methyl prednisolone pulse therapy for Graves' ophthalmopathy. Acta Ophthalmol 2010;88(5):e154-9. doi: 10.1111/j.1755-3768.2010.01941.x.

38. Su TY, Ho WT, Lu CY, Chang SW, Chiang HK. Correlations among ocular surface temperature difference value, the tearmeniscus height, Schirmer's test and fluorescein tear film breakup time. Br J Ophthalmol 2015;99(4): 482-7.

39. Morgan PB, Soh MP, Efron N. Corneal surface temperature decreases with age. Cont Lens Anterior Eye 1999;22(1):11-3.

40. Kamao T, Yamaguchi M, Kawasaki S, Mizoue S, Shiraishi A, Ohashi Y. Screening for dry eye with newly developed ocular surface thermographer. Am J Ophthalmol 2011;151:782-91.

41. Versura P, Giannaccare G, Fresina M, Campos EC. Subjective discomfort symptoms are related to low corneal temperature in patients with evaporative dry eye. Cornea 2015;34:1079-85.

42. Craig JP, Singh I, Tomlinson A, Morgan PB, Efron N. The role of physiology in ocular surface temperature. Eye 2000;14:635-41. 